\title{
Association between scrotal circumference, live weight and sperm output in cattle
}

\author{
A. P. Carter, P. D. P. Wood and Penelope A. Wright \\ Milk Marketing Board, Thames Ditton, Surrey KT7 OEL, U.K.
}

\begin{abstract}
Summary. The relationships between scrotal circumference and live weight and sperm output were examined in 3 samples of bulls selected for use in AI. In Study 1 the linear correlation between live weight and scrotal circumference in 418 British Friesian bulls at about 400 days of age was +0.28 , and the circumference of the scrotum was related to the live weight of the bull by $+0.179 \pm 0.060 \mathrm{~mm} / \mathrm{kg}$ live weight. At 400 days of age the mean ( \pm s.e.) live weight and scrotal circumference of 22 British Friesian bulls in Study 2 was $412 \pm 7 \mathrm{~kg}$ and $332 \pm 4 \mathrm{~mm}$ respectively. Rates of growth were $1.11 \pm 0.023 \mathrm{~kg} / \mathrm{day}$ and $0.426 \pm 0.023 \mathrm{~mm} / \mathrm{day}$. The correlation $(+0.42)$ between the size of the scrotum and the no. of spermatozoa/ ejaculate was not significant. British Friesian (average age 9 years) and Hereford (average age 6.5 years) bulls were examined in Study 3. For the 25 Herefords, the correlation between the number of usable straws over a 6-month period and the scrotal circumference was +0.43 , compared with +0.21 among the 28 British Friesians. It is concluded that scrotal circumference is unlikely to be an accurate predictor of sperm output in AI bulls.
\end{abstract}

\section{Introduction}

Bovine spermatozoa produced in the testes pass into the epididymides where they mature and remain until ejaculated. Sperm output, defined as the number of spermatozoa collected by means of an artificial vagina, may vary according to libido, pre-ejaculation stimulation, collecting technique, fitness, frequency of collection and rate of sperm production (Hale \& Almquist, 1960 ). The relationship between sperm production and sperm output is not a simple one. The extragonadal reserves can be affected by leakage into the urine, absorption and masturbation, and ejaculation. For optimal usage of resources, leakage clearly should be reduced to a minimum (Almquist \& Amann, 1961) and sperm production and output by ejaculation should be at a maximum for bulls used in artificial insemination (AI) programmes.

Attempts to identify predictors of sperm output have been reported in the literature. Amann \& Almquist (1962) found a high correlation between sperm production and the weight of the testes, and testicular weight has been reported to be closely correlated $(+0.53)$ with the scrotal circumference in the live animal (Willet \& Ohms, 1957). Testis measurements generally were positively correlated with the output of spermatozoa obtained by frequent ejaculation (Boyd \& VanDemark, 1957; Almquist \& Amann, 1961; Adrich, 1976). VanDemark \& Maager (1964) noted a positive correlation between scrotal circumference and liveweight, especially in bulls over 18 months of age, although Amann (1970) was later unable to repeat this finding. Using wither height as an indication of body size, Hahn, Foote \& Seidel (1969) found that generally there was a low correlation, below +0.39 , with testis size, indicating that larger, faster growing bulls did not necessarily have larger testes than did smaller bulls of the same age. However, a high 
correlation was found between sperm output and testis size in younger animals $(+0.81)$, although it declined with age.

The rate of production of spermatozoa has been shown to vary not only with age but also with season and management (Lodge \& Salisbury, 1970; Coulter \& Foote, 1976); breed differences have been noted by Coulter, Larson \& Foote (1975). Nevertheless, Foote, Hahn \& Larson (1970) suggested that measurements of a bull's testis and its consistency could be used with age to predict sperm output. Such a correlation would be useful and practicable because variations due to age and management, for example, could be eliminated by taking scrotal measurements at a predetermined age from bulls which had undergone the same management since calf-hood.

The study reported here was undertaken with a view to establishing a predictive technique based on scrotal circumference. The relationships between live weight, scrotal circumference and output of spermatozoa in young British Friesian bulls during rearing and subsequent use in AI and the association between sperm output and scrotal circumference in some mature British Friesian and Hereford bulls in regular use in AI were examined.

\section{Materials and Methods}

\section{Study 1}

The relationship between the 400-day live weight and scrotal circumference ( 2 testes) for young bulls was estimated from 418 British Friesian bulls at the Milk Marketing Board's Bull Rearing Unit at Chippenham, Wiltshire, England. Two operators made all measurements. With the bull restrained standing in a crate, one operator grasped the scrotum above the testes. This enabled a second operator to place a tape snugly around the scrotum. By exchanging roles, an agreed average circumference was obtained.

\section{Study 2}

British Friesian bull calves were selected at random from those entering the MMB Rearing Unit in the year ending March 1974. These 22 animals were weighed monthly and scrotal circumference was measured at the same time.

A cubic growth curve with a multiple correlation coefficient better than 0.96 for all animals was fitted to each set of live weight and scrotal measurements for each animal to remove nuisance variation arising from small random errors of measurement (Wood, 1970). The rate of growth at $\mathbf{4 0 0}$ days was calculated from the first derivative of the curve for each calf.

At about 14 months of age the bulls were distributed among 6 AI Centres. After arrival at the AI Centre, semen was collected for a dairy progeny test. The common aim for all Centres was to accumulate 800-1000 straws (doses of semen) as quickly as possible. This was generally achieved in about 1 month by weekly collections of 1-3 ejaculates after teasing the bull. The volume and density, obtained by using a colorimeter, were recorded and a visual subjective assessment was given for motility, by examination under a microscope at $40^{\circ} \mathrm{C}$. All ejaculates had to pass a standard recovery rate of a least $30 \%$ motility following freezing. Dilution was to $20 \times 10^{6}$ spermatozoa per straw. For those ejaculates that could be frozen successfully, the product of the volume and density gave the output (number of usable doses) and a mean output could be calculated for each bull.

\section{Study 3}

A further sample of 28 British Friesians and 25 Hereford bulls distributed among $4 \mathrm{AI}$ centres had been in active service for at least 6 months and were fit and healthy. These bulls were 
managed to give the maximum weekly output under the stud routine, in most cases 1 or 2 ejaculates, taken twice weekly. Laboratory standards were the same as in Study 2. The age and scrotal circumference of each bull were recorded after semen collection. A conventional linear multiple regression analysis of output on age and scrotal circumference was performed.

\section{Results}

\section{Study 1}

The mean live weight of the 418 British Friesian bulls at 400 days of age was $422 \mathrm{~kg}$ with a standard deviation of $30.8 \mathrm{~kg}$. Their mean scrotal circumference was $334 \mathrm{~mm}$, standard deviation $19.3 \mathrm{~mm}$. The correlation between the two measures was $+0.28 \pm 0.05$, leading to a regression equation of $S=258+0.179 W \pm 40.7 \mathrm{~mm} / \mathrm{kg}$, where $S$ is the scrotal circumference estimated from a 400-day live weight $W$.

\section{Study 2}

Mean live weight, scrotal circumference and semen parameters of the bulls in this sample are given in Table 1 . The correlation between live weights and scrotal circumference $(+0.41 \pm 0.23)$ was slightly but not significantly $(P>0.05)$ higher than in Study 1 . The equivalent relationship in this independent group was $S=230+0.246 \mathrm{~W} \pm 42.1 \mathrm{~mm} / \mathrm{kg}$. The standard error of the estimate in this equation was close to that obtained in Study $1(42.1$ and $40.7 \mathrm{~mm} / \mathrm{kg}$ respectively).

Table 1. Records of growth and scrotal circumference of 22 British Friesian bulls (Study 2)

\begin{tabular}{lcc}
\hline \multicolumn{1}{c}{ Character } & Mean & s.d. \\
\hline Live weight at 400 days of age (kg) & $411 \cdot 5$ & 34.1 \\
Live weight gain at 400 days (kg/day) & $1 \cdot 1 \pm 0.038$ & \\
Specific growth rate* $(\%)$ & $0 \cdot 26$ & \\
Scrotal circumference (mm) & $332 \cdot 3$ & 20.5 \\
Growth rate (mm/day) & $0.426 \pm 0.023$ & \\
Specific growth rate (\%) & $0 \cdot 12$ & \\
Volume per ejaculate (ml) & $4 \cdot 74$ & $1 \cdot 11$ \\
Mean density ( $\left.10^{6} / \mathrm{ml}\right)$ & 1180 & 300 \\
No. of ejaculates per bull & $4 \cdot 1$ & 1.7 \\
\hline
\end{tabular}

* The growth rate divided by the weight of the organ at the time.

The mean number of ejaculates needed to reach the Dairy Progeny Testing Scheme target was $4 \cdot 1$. The correlation between the total spermatozoa produced per ejaculate and the bull's scrotal circumference was $+0.42 \pm 0.23$, not significantly different from zero $(P>0.05)$.

\section{Study 3}

As shown in Table 2, the British Friesian Bulls were on average $2 \frac{1}{2}$ years older than the Herefords, had slightly larger scrota, and produced more doses of semen in the 6 month period. There was a tendency among the British Friesians for older animals to produce fewer doses than 
did younger bulls, i.e. about 800 doses per year of age. This trend was not reflected among the younger Hereford bulls. However, there was a tendency, in Herefords only, for bulls with large testes to produce more semen than did those with small testes, by about 100 straws per $\mathrm{mm}$ of circumference. In the Herefords, the correlation between output and circumference was $+0.43 \pm$ 0.20 , similar to the young British Friesians in Study 2 . This figure was just significantly different from zero at $5 \%$ probability. Among the Friesians the corresponding figure was $+0.21 \pm 0.19$ (N.S.).

Table 2. Mean \pm s.e.m. age, scrotal circumference and semen production (in straws during 6 months) of British Friesian and Hereford bulls (Study 3)

\begin{tabular}{lcc}
\hline \multicolumn{1}{c}{ Character } & British Friesian & Hereford \\
\hline $\begin{array}{l}\text { No. of bulls } \\
\text { Age (years) }\end{array}$ & 28 & 25 \\
$\begin{array}{l}\text { Scrotal circumference } \\
\text { (mm) }\end{array}$ & $933 \pm 0.4$ & $6.5 \pm 0.5$ \\
$\begin{array}{l}\text { Semen produced } \\
\text { (no. of straws) }\end{array}$ & $18000 \pm 1200$ & $14000 \pm 1300$ \\
\hline
\end{tabular}

\section{Discussion}

Is is important for AI bulls to give a plentiful supply of good quality semen. The market demand for some British Friesians, when introduced as proven sires at 7 years old, may exceed 100000 inseminations a year and it is a loss to the industry if the bull's output is lower than that. Measurements that will reliably predict a bull's output of spermatozoa would be useful at the time of his selection, or earlier if possible.

In the stallion and in the ass, El-Wishy (1974) found that sperm numbers in the epididymides were correlated with testis measurements, and El-Wishy \& Omar (1975) found sperm numbers in the camel were related to the weight of tissue $\left(40 \pm 15 \times 10^{6}\right.$ spermatozoa $\left./ \mathrm{g}\right)$. Significant correlations of sperm numbers with testis measurements have also been reported for rams (Lino, 1972) and boars (Rohloff, 1973). Our results with young bulls, however, did not show a useful relationship between scrotal circumference and sperm output. In agreement with Amann (1970) we found that the live weight of a bull at 400 days of age was not a good indicator of scrotal development. Nor was there a useful relationship between scrotal circumference and sperm output among the mature bulls of two breeds, even when ejaculates discarded because of motility were taken into account. It may well be that a functional relationship exists which could be realized in the right circumstances. That it should not always be realized in practice may be due to a number of reasons. Testis consistency, for example, measured by tonometry, was found by Foote et al. (1970) to be correlated with sperm production, but Davis, Langford \& Hirby (1970) noted that the capsule was in a constant state of movement, massaging non-motile spermatozoa out of the seminiferous tubules into the epididymides. This would lead to variations in size and consistency which might lead to spurious tonometer readings. Measurement of sperm production may not be exact. Young bulls may be over-eager, making collection difficult; they may not ejaculate completely into the artificial vagina. Mature bulls may be difficult to tease; they may become bored, and the number of teasing changes that can be tried is limited. The frequency of collection may not suit a particular bull.

It does not seem that scrotal measurements or live weight data on young bulls can be used with confidence to predict their future sperm production in the routine screening of sires for future use in AI. 


\section{References}

Adrich, S. (1976) Studies on the possibility of fertility prognosis in young bulls during growth. Zentbl. VetMed. A 23, 177-192.

Almquist, J.O. \& Amann, R.P. (1961) Reproductive capacity of dairy bulls. J. Dairy Sci. 44, 1668-1678.

Amann, R.P. (1970) Sperm production rates. In The Testis, vol. 1, pp. 433-440. Eds A. D. Johnson, W. R. Gomes \& N. L. VanDemark. Academic Press, New York.

Amann, R.P. \& Almquist, J.O. (1962) Reproductive capacity of dairy bulls. VIII. Direct and indirect measurement of testicular sperm production. J. Dairy Sci. 45, 774-781.

Boyd, L.J. \& VanDemark, N.L. (1957) Spermatogenic capacity of the male bovine. A measurement technique. J. Dairy Sci. 40, 689-697.

Coulter, G.H. \& Foote, R.H. (1976) Effect of season and year of measurement on testicular growth and consistency of Holstein bulls. J. Anim. Sci. 42 , 434-437.

Coulter, G.H., Larson, L.L. \& Foote, R.H. (1975) Effect of age on testicular growth and consistency of Holstein and Angus bulls. J. Anim. Sci. 41, 13811389.

Davis, J.R., Langford, E.A. \& Hirby, P.R. (1970) The testicular capsule. In The Testis, vol. 1, pp. 281-337. Eds A. D. Johnson, W. R. Gomes, \& N. L. VanDemark. Academic Press, New York.

El-Wishy, A.B. (1974) Testicular and epidimal sperm reserves in the ass (Equus asinus) and stallion (Equus caballus). Z. Tierzücht. Zücht Biol. 91, 334-344.

El-Wishy, A.B. \& Omar, A.M. (1975) On the relation between testis size and sperm reserves in the one humped camel (Camelus dromedarius). Beitr. trop. \& subtrop. landwirt. \& Tropenvet.-Med. 13, 391-398.

Foote, R.H., Hahn, J. \& Larson, L.L. (1970) Testicular measurements as predictor of sperm output and semen quality. Proc. 3rd Tech. Conference on AI \& Reproduction, Chicago, pp. 31-35. Cornell University, Ithaca.

Hahn, J., Foote, R.H. \& Seidel, G.E., Jr (1969) Testicle growth and related sperm output in dairy bulls. $J$. Anim. Sci. 29, 41-47.

Hale, E.B. \& Almquist, J.O. (1960) Relation of sexual behaviour to germ cell output in farm animals. $J$. Dairy Sci. 43 (Suppl), 145-169.

Lino, B.F. (1972) The output of spermatozoa in rams. Aust. J. Biol. Sci. 25, 359-366.

Lodge, J.R. \& Salisbury, G.W. (1970) Seasonal variation and male reproductive efficiency. In The Testis, vol. 3, pp. 139-167. Eds A. D. Johnson, W. R. Gomes \& N. L. VanDemark. Academic Press, New York.

Rohloff, D. (1973) Evaluation of daily sperm production in German Landrace boars. Zuchthygiene 8, 72-75.

VanDemark, N.L. \& Maager, R.E. (1964) Effect of energy intake on reproductive performance of dairy bulls. J. Dairy Sci. 47, 798-802.

Willett, E.L. \& Ohms, J.I. (1957) Measurement of testicular size and its relation to production of spermatozoa by bulls. J. Dairy Sci. 40, 1559-1569.

Wood, P.D.P. (1970) Factors affecting accuracy in the evaluation of progeny tests of growth rate in cattle. Anim. Prod. 12, 585-590. 